\title{
MIXED FERTILIZER AFFECT WHEAT (Triticum aestivum L.)GROWN IN CLAY AND LOAMY SOIL
}

\author{
Abbas, M. A.*; Samia A. Haroun*; S. H. Sarhan** and \\ Eman H. Abd El-Azeiz* \\ * Botany Department, Faculty of Science, Mansoura University. \\ ** Soil, Water and Environment Research Institute, ARC, Cairo.
}

\begin{abstract}
A pot experiment carried out at EL-Mansoura Lab. of Plant Nutrition Research, Soils, Water and Environment Res-Institute of Agricultural Research Center during two successive seasons (2009-2010 and 2010-2011) to investigate the influence of two levels of phosphorus (P1, P2) and potassium (K1, K2) in combination with nitrogen $(\mathrm{N})$ with or without activated mixed fertilizer dose(D1\&D2 respectively) on leaf area, relative water content and photosynthetic pigments content of flag leaf during tillering, heading and anthesis growth stages as well as yield attributes and biochemical aspects of the yielded grains of wheat plant grown in both clay and loamy soils.

In wheat plants grown in clay soil a significant value of all studied characters were recorded in response to combination of lower phosphorus concentration, higher potassium concentration (P2K1) and nitrogen without activated dose. While, in loamy soil these characters were linearly increased in wheat plants treated with combination of higher phosphorus concentration and lower one of potassium (P1K2) and nitrogen without activated dose.
\end{abstract}

Keywords: Wheat, mixed fertilizers, clay and loamy soil, growth, pigments, yield.

\section{INTRODUCTION}

Wheat (Triticum aestivum L.) belongs to grass (poaceae) family; which can be grown in a variety of soils and climates. In Egypt, as in many other countries of the third world, there is an extreme shortage in wheat production. Therefore, increasing wheat production is an essential target in these contain.

The importance of minerals in plant growth was known since very early days of cultivations and nowadays frequent use of different fertilizers has changed the life pattern of all crop plants (Aldesuquy, 2000).Fertilization in modern agriculture not only maintains, but even gradually increases field crop yield. The most familiar categories of fertilizers are synthetic (inorganic) and natural (organic).The synthetic fertilizers consist almost entirely of nitrogen, potassium and phosphorus which are usually of quick release formulas making rapid availability to plants (Mahdi and Omran, 2003).Fertilization can be divided into mixed and complex ones. The mixed one contains two or more of the elements; nitrogen, phosphorus and potassium (NPK) which are essential for good plant growth and high crop yield. The complex fertilizers mean a fertilizer containing two or more nutrients; during the production of which chemical reaction takes place (Arief et al., 2006).

Macronutrients (N, P and $\mathrm{K}$ ) are key elements in the nutrition of most crops, especially cereals and their addition increased significantly yield and 
Abbas, M. A. et al.

yield components of wheat (Mahrous et al., 2010). In another study, the combined application of $\mathrm{N}, \mathrm{P}$ and $\mathrm{K}$ has proved to be more effective in increasing yield of wheat as compared to sole application of either $\mathrm{N}$ or $\mathrm{P}$ or K (Cheema and Ali ,2003).

Nitrogen is an element limiting plant growth in many ecosystems, its availability and internal distribution plays a critical role in the regulation of various growth related and morphogenetic aspects of plant development that are usually attributed to hormonal factors (Palta et al., 2005). Nitrogen is an essential constituent of proteins, nucleic acid and many other organic molecules (e.g. chlorophyll) and thus plays an important role in plant life. (Jamal et al., 2006).

Phosphorus is an important nutrient for crop production. It is an essential constituent of lipoprotein membranes of cell, nucleoproteins, many co - enzymes and organic molecules such as ADP, ATP and NADP which play an important role in the energy transfer reactions of cell metabolism and in oxidation - reduction reactions (Kochhar and Krishnamoorthy, 1988). It is also necessary for the functioning of mitochondria, which are the centers of cellular respiration (Ewa and Jolanta, 2005).

Inspite of the fact that potassium does not enter into the composition of any organic compound in the plant body, it is needed by the plant in large quantities .Its probable role is to provide the necessary ionic back- ground which is in some way in dispensable for the maintenance of the living entity of the protoplasm. Moreover, it plays a crucial role in the plant metabolism where, it is involved in activating a wide range of enzyme systems that regulate photosynthesis, protein synthesis, stomotal movement, water relation and movement of nitrogen uptake in plant (Marschner, 1995 and Thalooth et al., 2006).

Photosynthesis is a key metabolic pathway in plants. Many authors have established chlorophyll and carotenoids synthesis is dependent upon mineral nutrition (Bojovic and Markovic, 2009).

This work is planned to investigate the response of wheat plant, grown in two types of soil, to mixed fertilizers application through following growth criteria, photosynthesis pigments as well as yield attributes and the biochemical aspects of the yielded grains; total protein and total carbohydrates.

\section{MATERIALS AND METHODS}

Pure strain of wheat (Triticum aestivum L.) seeds var. Sakha 93 used in the present study were kindly supplied from Agriculture Research Center, Giza, Egypt. Both clay and loamy soil used in this study were taken from surface layer (0-30 cm deep) of agriculture field located in Mansoura District - Dakahlia Governorate. Representative soil samples were taken from the air dried experimental soil, ground, sieved through $2 \mathrm{~mm}$ sieve and analyzed for some physical and chemical properties according to Black (1965) as shown in Table (1). 
Table 1: Average values of chemical and physical properties of the used experimental soils

\begin{tabular}{|c|c|c|c|c|c|c|c|c|c|c|c|c|c|c|c|c|c|}
\hline \multirow[b]{2}{*}{ Soil } & \multicolumn{8}{|c|}{$\begin{array}{c}\text { lons } \\
\text { ( } \mathrm{meg} / 100 \mathrm{gm} \text { soil ) }\end{array}$} & \multicolumn{6}{|c|}{$\begin{array}{c}\text { Physical properities } \\
\%\end{array}$} & \multicolumn{3}{|c|}{$\begin{array}{c}\text { Available } \\
\text { nutrients } \\
\text { ( ppm) }\end{array}$} \\
\hline & 声 & $\stackrel{+}{+\infty}$ & $\stackrel{+\infty}{\mathbf{2}}$ & $\stackrel{+}{ \pm}$ & סू & 恣. & '̊̀ & ত & 疍 & 志 & $\frac{\vec{\pi}}{0}$ & $\sum_{0}$ & Ü & $\frac{I}{2}$ & $z$ & 0 & 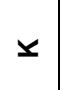 \\
\hline Clay & 6.00 & 1.00 & 3.55 & 0.20 & 0.00 & 2.00 & 2.75 & 6.00 & 22.13 & 17.79 & 60.0 & 1.90 & 2.15 & 8.14 & 44.9 & 14.6 & 336 \\
\hline Loamy & 7.00 & 1.00 & 1.65 & 0.10 & 0.00 & 0.40 & 1.35 & 8.00 & 12.30 & 47.7 & & & & 794 & 48 & 12.3 & 370 \\
\hline
\end{tabular}

\section{The experimental design and treatments:-}

In this study, mixed fertilizers were prepared by different concentrations of $\mathrm{N}, \mathrm{P}$ and $\mathrm{K}$, where urea $(46 \% \mathrm{~N})$, calcium super-phosphate $\left(15 \% \mathrm{P}_{2} \mathrm{O}_{5}\right)$ and potassium sulfate $\left(48 \% \mathrm{~K}_{2} \mathrm{O}\right)$ were used as a source of $\mathrm{N}, \mathrm{P}$ and $\mathrm{K}$ respectively.

Urea was added to the all treatments except -ve control, [P1 and $\mathrm{K}_{1}$ (100\% of recommended), while $\mathrm{P}_{2}$ and $\mathrm{K}_{2}$ (50\% of recommended)]. In addition to -ve control without any fertilizer and +ve control with $\mathrm{N}$ fertilizer. The application of the mixed fertilizer of $\mathrm{P}$ and $\mathrm{K}$ takes places in two ways (D1 \& D2):

In the first (D1), an activation dose was applied where the pots received activated dose (20\%) of fertilizers before sowing and two successive doses each of $40 \%$ at two periods, 21 days per longed was applied .

In the second application (D2); no activation dose i.e. fertilizers were divided into two equal doses each of $50 \%$ which applied after 21 and 42 days from sowing, respectively.

Thus the used treatments were as follows

1- $\mathrm{NP}_{1} \quad\left(100 \% \mathrm{P}\right.$ of recommended) $3-\mathrm{NK}_{1}(100 \% \mathrm{~K}$ of recommended $)$

2- $\mathrm{NP}_{2}$ (50\% $\mathrm{P}$ of recommended) 4- $\mathrm{NK}_{2}$ (50\% K of recommended)
5- $\mathrm{NP}_{1} \mathrm{~K}_{1}$
6- $\mathrm{NP}_{1} \mathrm{~K}_{2}$
7- $\mathrm{NP}_{2} \mathrm{~K}_{1}$
8- $\mathrm{NP}_{2} \mathrm{~K}_{2}$

The pots were kept under a normal day / night conditions and irrigated as usual practice with equal amounts of tap water when required.

The collected samples at the first three stages from sowing which represent tillering, heading and anthesis respectively were used for assessment of growth parameters total leaf area / plant and relative water content, as well as pigments content .In addition yield attributes of the yielded grain (grain yield / plant, straw yield / plant, crop yield / plant, crop index, harvest index, mobilization index and relative grain yield) as well as some chemical aspects of the yielded grains were also determined.

It should be mentioned that, for growth parameters and at yield stages ten determinations were made for each characters whereas triplicate samples were analyzed for leaf area, relative water content, photosynthetic pigments as well as yield attributes and biochemical aspects of the yielded grains, but only the mean values are presented in the respective tables.

\section{Analytical methods:-}

Relative water content \% (El -Sharkawi and Salama, 1973) and leaf area (Turner, 1974) were determined. Photosynthetic pigments determined 
Abbas, M. A. et al.

according to the spectrophotometric method as recommended by Arnon (1949) for chl and Horvath et al. (1972) for carotenoid as adopted by Kissimon (1999), yield and yield attributes; seed index = is the weight of 1000 seeds (Gregory, 1988), harvest index= economic yield (grain yield) / biological yield (above ground dry matter) x 100 (Beadle, 1993), relative grain yield=yield of treated plant / yield of untreated (normal) plant x 100 (Beadle, 1993),crop index = grain yield / biological yield (grain yield + straw yield) (Beadle, 1993) and mobilization index = Crop yield / straw yield (Ray and Choudhuri, 1980), as well as biochemical aspects of yielded grains; polysaccharides (Thayermanavan and Sadasivam 1984) and total protein in the plant according to Bradford (1976).

The full data of the differently treated groups were statistically analysed and comparison among means was carried out by computer programming method (statgraphic-vers-4-2-Display ANOVA) as described by Snedecor and Cochran (1982).

\section{RESULTS AND DISCUSSION}

\section{Changes in leaf area and relative water content:}

Statistical analysis of results in Table 2 showed that, all of the conducted treatments caused a significant increase in leaf area and relative water content at tillering, heading and anthesis stage of wheat grown in the two types of soil ( clay \& loamy).In case of fertilization using activated dose ( D1) data showed that, leaf area and relative water content were gave the highest values at mixed fertilizer P1 \& P2 treatments in clay and loamy soil respectively as compared to control .While the mixed fertilizer without activated dose induced the highest increase in all these parameters in the plant growing in the two types of soil comparing to control and the fertilizers with activated dose where treatment with P2K1 in clay soil and P1K2 in loamy soil achieved the highest significant increase. These results are in good conformity with those obtained by Ihsan et al. (2007) studied the effect of different methods of fertilizer applications to wheat after germination under rainfeed condition, the data showed that, applying of both fertilizers (N\&P) gave maximum increase in flag leaf area, number of grain spike, 1000- grain weight and grain yield. Also, Sabrina et al. (2011) reported that NPK fertilizer causes increase in water content of wheat plant.

\section{Changes in pigment content:-}

Throughout the different stages of wheat growth and development, all the determined photosynthetic pigments (chl a, chl b, and carotenoids) total chlorophyll and consequently total pigments were significantly increased with fertilization treatments. Thus, the highest significant values of increments; in case of fertilization with activated dose, was more pronounced in plant treated with P1 in clay soil and P2 in loamy soil. Meanwhile, the significant increase was clearly noticed in case of fertilization without activated dose by the application of P2K1 in clay soil and P1K2 in loamy soil (Tables 3a, b and c). In this respect, chlorophyll and carotenoids synthesis is dependent upon mineral nutrition (Amaliotis et al., 2004 and Lelyveld et al., 2004). 
J. Plant Production, Mansoura Univ., Vol. 3 (4), April, 2012

2 
Abbas, M. A. et al.

Also, Bojovic and Markovic (2007) studied the viability of the leaf of wheat under conditions of different soil fertilization and stated that, chlorophyll content is dependent on mineral nutrition and fertilization with nitrogen and phosphorus (N P) was exert the great influence on chlorophyll content. Moreover, Vijay et al. (2009) studied the influence of nitrogen, phosphorus and potassium fertilizer on biochemical contents of Asparagus racemosus and demonstrated that, a significant increase in the chlorophyll content was recorded with the application of $\mathrm{N}, \mathrm{P}$ and $\mathrm{K}$.

Yield attributes:-

Balanced fertilizer nutrients can play a vital role in sustaining high yield of wheat plants as well as maintaining fertility status of soils on long - term basis (Carasky and Iwuafor, 1999). In this connection, the data presented in Table 4 clearly showed that, in the majority of cases, the application of mixed P2K2 fertilization with activated dose (D1) in clay soil and K2 in loamy soil caused the highest significant increase in grain yield, straw yield, crop yield / plant as well as relative grain yield, whereas $\mathrm{K} 1$ treatment with activated dose achieved the highest values of harvest index, mobilization index and crop index in both clay and loamy soil.

Regarding fertilization without activated dose (D2), the highest values of grain, straw, crop yield / plant and relative grain yield were observed by P1K2 in clay soil and P2K1 in loamy soil. Meanwhile the harvest index, mobilization index and crop index were increased mostly by mixed P1 in clay and mixed K2 in loamy soil. In this respect, Abbas et al. (2000) found that fertilizer increased wheat highet, no. of tillers per unit area, grain yield and straw yield. The same results were more or less reported by Gill et al. (2001). Furthermore, combined application of NP has a better effect in enhancing the seed yield which is coincided with higher total dry matter and higher concentration of nutrients in leaf at flowering growth stage in wheat plant (El Gizawy, 2009).

In this study, the observed increases in the determined yield attributes of wheat plants in response to the used treatments (Table4) are a good reflection to the stimulation detected in total leaf area, relative water content (Table 2), photosynthetic pigments (Tables $3 a, b$ and c) of wheat shoot. In this connection, Kakar et al.(2002) found that NPK fertilizer increases the vegetative growth as well as a gradual increase in total yield/ fed. Also, Thalooth et al. (2006) and Cheema et al.( 2007) pointed out that, nitrogen is a constituent of amino acids, nucleic acids and enzymes so, it is important for both plant growth and yield. In addition, fertilization of wheat with NPK during vegetative stages could result in an increased growth and higher yield (Sabrina et al., 2011).

Changes in some biochemical aspects of the yielded grains:-

Perusals of the data in Table 5 revealed that, the estimated values of protein and carbohydrates content in the yielded grains were significantly higher than that of control values. The most improved protein and carbohydrate content was detected by application of mixed P2K1 in clay soil and mixed P1K2 in loamy soil, without activated dose comparing with control and other treatments. 
J. Plant Production, Mansoura Univ., Vol. 3 (4), April, 2012

3

645 
Abbas, M. A. et al.

3 
J. Plant Production, Mansoura Univ., Vol. 3 (4), April, 2012

3 
Abbas, M. A. et al.

4 
J. Plant Production, Mansoura Univ., Vol. 3 (4), April, 2012

5

649 
Abbas, M. A. et al.

These results are in agreement with those of Mahrous et al. (2010) who found that, percentage of crude protein significantly increased with inorganic fertilizer more than organic fertilizer or micronutrients mixture. Moreover, Sabrina et al. (2011) observed that the gradual increase of NPK fertilizer causes a gradual increase in crude protein, total sugars, reducing sugars, starch and soluble carbohydrates.

The observed increments in the photosynthetic pigments (Tables $3 a \& 3 b$ ) of treated wheat plant leaves is supported by the stimulation of leaf area (Table 2) and yield attributes (Table 4) as well as biochemical aspects of the yielded grain ; protein and total carbohydrates (Table 5).In this connection, Koth (1998) stated that, the favorable effect of NPK fertilizer might be explained by assuming an influence of $\mathrm{N}$ availability on critical stage of spike initiation and development of plant metabolism in a way leading to the increase in the synthesis of amino- acid and their incorporation in to grain protein

In conclusion, it is obvious from the results of the present investigation that, wheat plant grown in clay or loamy soil was affected by different rate of phosphorus $\left(\mathrm{P}_{1}, \mathrm{P}_{2}\right)$ and potassium $\left(\mathrm{K}_{1}, \mathrm{~K}_{2}\right)$ in combination with nitrogen. In addition, the statistical analysis of results show that, the combination of lower phosphorus concentration, higher potassium concentration and nitrogen without activated dose induced the highest values of flage leaf area, relative water content, pigments content as well as yield attributes and biochemical aspects of the yielded grains of wheat plant grown in clay soil. While, in loamy soil, the highest values of all these characteristics were recorded in wheat plants treated with combination of higher phosphorus concentration, lower one of potassium and nitrogen (NP1K2) without activated dose application. This conclusion is confirmed by Cheema et al. (2007) who stated that the fertilizer plays a significant role towards the enhancement of yield per unit area of all crops and wheat is no exception to it.

From these results, it could be concluded that, in wheat plant, the combined application between the lower phosphorus concentration, higher potassium concentration and nitrogen $\left(\mathrm{NP}_{2} \mathrm{~K}_{1}\right)$ is more effective in clay soil. Whereas, combination of higher phosphorus concentration with the lower one of potassium in addition to nitrogen $\left(\mathrm{NP}_{1} \mathrm{~K}_{2}\right)$ have the best results in loamy soil without activated dose.

\section{REFERENCES}

Abbas, G.; Irshad, A. and Ali, M. (2000): Response of three wheat (Triticum aestivum L.) cultivars to varying applications of $\mathrm{N}$ and P. Int.J.Agri.Biol., 2(3):237-238.

Aldesuquy, H.S. (2000): Effect of indol -3- acetic acid on photosynthetic charachteristics of wheat flage leaf during grain filling photosynthetica .38:135-141. 
Amaliotis, D.; Therios, I.; Karatisson, M. (2004): Effect of nitrogen fertilization on growth, leaf nutrient concentration and photosynthesis in three peach cultivars. ISHS Acta Horticul., $\quad$ 449: 36-42.

Arief, M.; Chohan, M. A. and Khan, S. (2006): Response of wheat to foliar application of nutrients .Journal of Agric. and oBil. Sci . 1(4): 119-123.

Arnon, D.I. (1949): Copper enzymes in isolated chloroplasts: Polyphenol oxidase in Beta vulgaris. Plant Physiol. Plant Physiol., 24:1-15.

Beadle,C.L.(1993):Growth analysis .In:Photosynthesis and production in a changing environment. A field and laboratory manual ( eds. DC Hall, J M O Scurlock, H R Bolhar- Nordenkampf, R C Leegod, S P Long), Chapman and Hall, London, 36-46.

Black, C.A. (1965):"Methods of soil analysis" Part 2. American Society of Agronomy, Inc.Publisher, Madison,Wisconsin,USA.

Bojovic, B. and Markovic, A. (2007): Variability of the leaf of Triticum aestivum L. under conditions of different soil fertilization. Arch. Biol. Sci., Belgrade, 59 (2): 29-30.

Bojovic, B. and Markovic, A. (2009): Correlation between nitrogen and chlorophyll content in wheat Kragujevac J. Sci., 31: 69-74.

Bradford,M.M.(1976):A rapid and sensitive method for the quantitative of microorgan quantities of protein utilizing the principle of protein dye binding .Annal.Biochem.,72:248.

Carasky, R. J. and Iwuafor, E.N.O. (1999): Contribution of soil fertility research and maintenance to improve maize production and productivity in Sub- Saharan African. Proceeding of regional maizeworkshop. Strategy for sustainable maize production in west and central Africa, April 21-25, International Institute for Tropical Agriculture (U T A) -Cotonou, Benin Republic, pp:3-20

Cheema, M. S. and Ali, L. A.M.(2003): Effect of seed rate and NPK fertilizer on growth and yield of wheat variety Punjnad-1. Pak.J.Agron., 2(4):185-189.

Cheema, N.M.; Ihsan, M.; Mian, M.; and Mahmood, A. (2007): Effect of different methods of fertilizer application to wheat after germination under rainfed conditions.J.Agric.Res.45 (4).on wheat plant. Egypt, J. Appli. Sci., 22(4):376-389.

El-Gizawy, B. Kh. N. (2009): Effect of planting date, fertilizer application on yield of wheat under no till system .World J. of Agric. Sci., 5 (6): 777-783.

El-Sharkawi, H. M.; and Salama, F. M. (1973): Drought resistance in some wheat and barley cultivars .I. Analysis of transpiration curves, II. Adjustment in internal water balance. Proc. $7^{\text {th }}$ Arab.Sci.Conf, Cairo (Sept.23)

Ewa, S.G.; and Jolanta, K. (2005): Effect of excessive zinc content in soil on the phosphorus content in wheat plants. Elect. J. of polish Agric.

Univ., 8(4): $47-52$

Gregory, P. J. (1988): Crop growth and development. In: Ressell's Soil Conditions and Plant Growth (Ed. A. Wild), pp: 31-68,Longman Scientific Technical, U. K. 
Gill, K. H.;Sherazi, S. J. A.;lqbal, J.;Sheikh, A. A; Ramzan, M. and Shaheen, M. K. (2001): Evaluation of different NP rates in maize in central and barani zone of the Punjab. Pak. J. Soil Sci., 20:81-5.

Horvath,G.; Kissimon,J. and Faludi, D.A. (1972):Effect of light intensity of carotenoids in normal and mutant leaves . Phytochem. 11:183-187.

Ihsan, M.; Mahmood, A.; Mian, M. A. and Cheema, M. N. (2007): Effect of different methods of fertilizer application to wheat after germination under rainfed conditions. J. Agric. Res., 45(4):28-32

Jamal, Z.; Hamayun, M.; Ahmed, A.; and Chaudhary, M.F. (2006): Effects of soil and foliar application of different concentrations of NPK and foliar application of $\left(\mathrm{NH}_{4}\right)_{2} \mathrm{SO}_{4}$ on different yield parameters in wheat. J.of Agron.5 (2):251-256.

Kakar, K.M.; Arif, M.; and Nawab, K. (2002): Comparative assessment of phosphorus form for wheat applied at different stages .Pak. J. Soil Sci.; 21(4):14-20.

Kissimon, J.( 1999): Analysis of the photosynthetic pigment composition. Iner. Workshop and training course on Microalgal Biol And Biote ch Mosonmagyar.,Hungary pp 13-26.

Kochhar, P.L. and Krishnamoorthy, H.N. (1988): A text Book of Plant Physiology, pp: 174,175,165-168,178,180.

Koth, M. A., (1998): Response of wheat to bio-fertilizer and inorganic $\mathrm{N}$ and P levels. J. Agric. Sci. Mansoura Univ., 23(9):4067-4078.

Lelyveld , L. J.; Smith, B. L. and Frazer, C. (2004): Nitrogen fertilization of tea : Effect on chlorophyll and quality parameters of processed black tea .Acta Hortic.275:168-180.

Mahrous, M.N.; Sallam, M.A.; Sadek, G.J. and Shaban, A.K. (2010): Improving wheat production and grain quality by inorganic, organic and some micronutrients fertilizers under saline condition. Res. J. of Agric. and Biol. Sci., 6(6):1087-1098.

Mahdi, A.M. and Omran, M.M. (2003): Effect of soil and foliar application of phosphorus as well as molybdenum on yield component and chemical composition of faba bean. Egypt.J.Appli.Sci. 18(3B)

Marschner, H. (1995): Mineral nutrition of higher plants.2nd Ed. Academic Press, San Diego, California, USA.

Palta, J.A.; Nadwal, A.S.; Kumari, S. and Turner, N.C. (2005): Foliar nitrogen application increases the seed yield and protein content in chickpea subject to terminal draught. Austr. J. of Agric. Res., 56(2):105-112.

Ray, S. and Choudhuri, M. A. (1980): Regulation of flag leaf senescence in rice by nutrients and its impact on yield. Phsiol. Plant. 59:343-346

Sabrina,B.;Mohammed,D.;Rachid,R.;Kamel.,R.andHouria,B.(2011): orrelation between changes in biochemical roots of wheat and stress induced by some regimes fertilizer NPK .Amer.Eura. J. of Toxicol. Sci., 3(1): 47-51.

Snedecor,G.W. and Cochran,W.G. (1982):Statistical Methods. 6th Ed. Oxforord IBH Publishing Co.New.Delhi. 
Thalooth, A.T.; Tawfik, M.M. and Mohamed, H.M. (2006): A comparative study on the effect of foliar application of zinc, potassium and magnesium on growth, yield and some chemical constituents of mung bean plants grown under water stress conditions .World J. of Agric. Sci., 2(1):37-46.

Thayermanavan,V. and Sadasivam, S. (1984):Quall plant foods.Hum.Nut., 34, 253-257.Quoted from Biochemical Methods.( Sadasivam ,S. and A. Manikam, eds ) 2 nd ed., 11-12. New Agr. Inter.Publ. New Delhi, India.

Turner, N.G. (1974): Stomotal behavior and water status of maize, sorghum and tobacco under field conditions. II. At low soil water potential. Plant Physiol., 53:360-365.

Vijay, N.; Kumar, A. and Bhoite, A. (2009): Influence of nitrogen, phosphorus and potassium fertilizer on biochemical contents of Asparagus racemosus root tubers. Res. J. of Environ. Sci., 3: 285-291.

$$
\begin{aligned}
& \text { تأثير الاسمده المخلوطه على نبات القمح النامى فى التربه الطينيه والطمييه }
\end{aligned}
$$

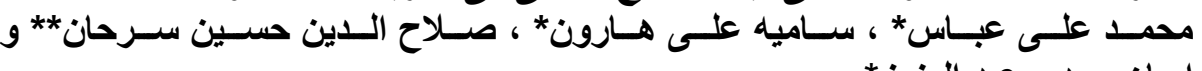

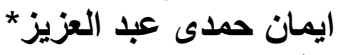

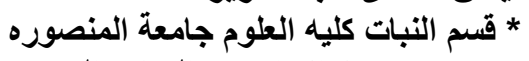

$$
\begin{aligned}
& \text { * * معهز بحوث الار اضى والمياه والبعة البيئه - مركز البحوث الزراعية }
\end{aligned}
$$

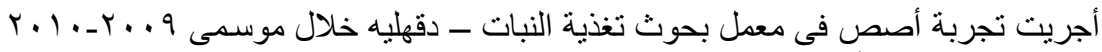

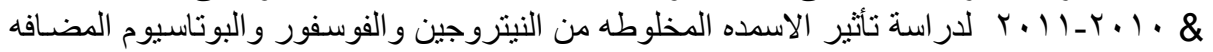

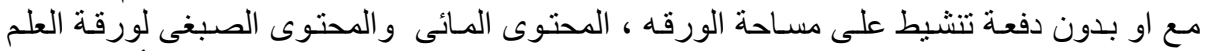

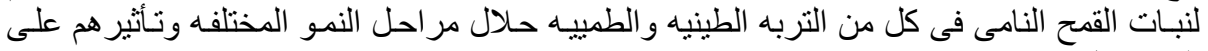

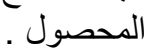

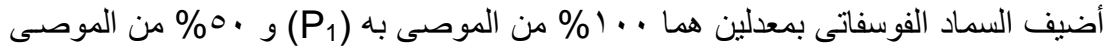

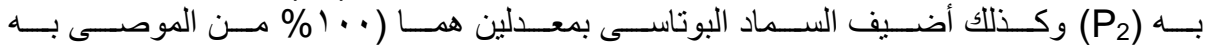

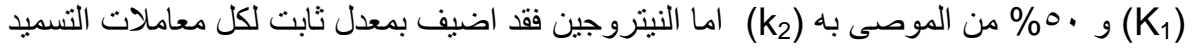

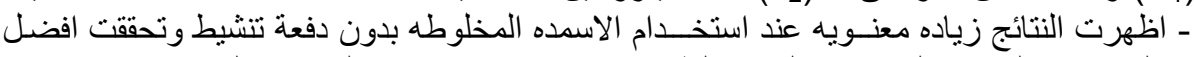

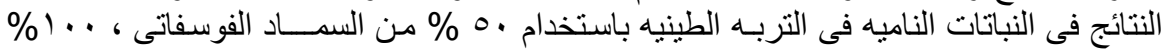

$$
\begin{aligned}
& \text { من السماد البوتاسى مخلوطين مع النيتروجين ( NP2 }
\end{aligned}
$$

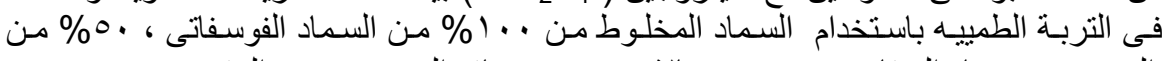

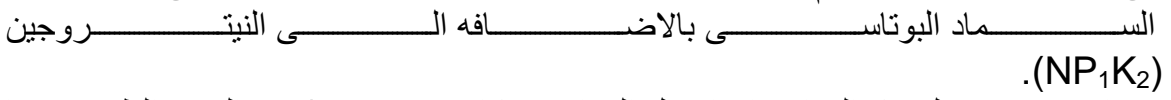

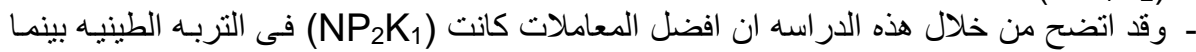

$$
\begin{aligned}
& \text { كانت المعامله (NP1 }) \text { هى الافضل فى التربه الطمييه وبدون دفعة تنتشيط }
\end{aligned}
$$

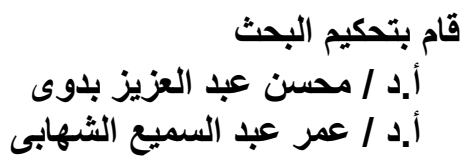


Abbas, M. A. et al. 
Table 2: Effect of mixed fertilizers on leaf area and relative water content of wheat plants grown in clay and loamy soil at different vegetative growth stages.

\begin{tabular}{|c|c|c|c|c|c|c|c|c|c|c|c|c|c|}
\hline \multirow{3}{*}{\multicolumn{2}{|c|}{$\begin{array}{c}\text { Treatments } \\
\text { Parameters } \\
\text { stages }\end{array}$}} & \multicolumn{6}{|c|}{ Clay } & \multicolumn{6}{|c|}{ Loamy } \\
\hline & & \multicolumn{3}{|c|}{ Leaf area } & \multicolumn{3}{|c|}{ R.W.C. } & \multicolumn{3}{|c|}{ Leaf area } & \multicolumn{3}{|c|}{ R.W.C. } \\
\hline & & Tillering & Heading & Anthesis & Tillering & Heading & Anthesis & Tillering & Heading & \begin{tabular}{|l|} 
Anthesis \\
\end{tabular} & Tillering & Heading & Anthesis \\
\hline \multicolumn{2}{|c|}{ Cont -ve } & 2.99 & 4.15 & 5.17 & 17.24 & 23.92 & 29.80 & 4.21 & 6.79 & \begin{tabular}{|l|}
18.73 \\
\end{tabular} & 19.08 & 30.77 & 61.80 \\
\hline \multicolumn{2}{|c|}{ Cont +ve } & 5.83 & 6.70 & 9.71 & 23.57 & 27.16 & 39.36 & 6.79 & 10.60 & 20.68 & 26.21 & 40.90 & 64.10 \\
\hline \multirow{8}{*}{ D1 } & NP1 & $8.50^{*}$ & $13.87^{*}$ & $14.13^{*}$ & $39.21^{*}$ & $67.48^{*}$ & $69.73^{*}$ & $8.44^{*}$ & $12.77^{*}$ & $18.73^{*}$ & $32.03^{*}$ & $48.32^{*}$ & $61.80^{*}$ \\
\hline & NP2 & $7.48^{*}$ & $11.09^{*}$ & $12.52^{*}$ & $38.13^{*}$ & $61.17^{*}$ & $67.43^{*}$ & $9.14^{\star}$ & $14.44^{*}$ & $20.68^{*}$ & $32.73^{*}$ & $53.16^{*}$ & $64.10^{*}$ \\
\hline & NK1 & $7.80^{*}$ & $12.49^{*}$ & $13.66^{*}$ & $38.52^{*}$ & $62.13^{*}$ & $67.96^{\star}$ & $7.39^{\star}$ & $10.12^{*}$ & $17.82^{*}$ & $31.00^{*}$ & $40.03^{*}$ & $58.74^{*}$ \\
\hline & NK2 & $8.37^{*}$ & $13.67^{*}$ & $14.10^{*}$ & $39.03^{*}$ & $67.01^{*}$ & $69.45^{*}$ & $7.22^{*}$ & $8.85^{\star}$ & $16.59^{*}$ & $30.59^{*}$ & $36.36^{*}$ & $54.01^{*}$ \\
\hline & NP1K1 & $8.15^{\star}$ & $13.43^{*}$ & $13.67^{*}$ & $38.71^{*}$ & $62.60^{*}$ & $68.82^{*}$ & $8.58^{*}$ & $13.41^{*}$ & $19.32^{*}$ & $32.21^{*}$ & $50.65^{*}$ & $61.85^{*}$ \\
\hline & NP1K2 & $6.97^{*}$ & $10.15^{*}$ & $12.02^{*}$ & $37.22^{*}$ & $58.41^{*}$ & $66.76^{*}$ & $7.61^{*}$ & $10.93^{*}$ & $17.89^{*}$ & $31.18^{*}$ & $40.35^{*}$ & $59.02^{*}$ \\
\hline & NP2K1 & $6.43^{*}$ & $10.12^{*}$ & $11.96^{*}$ & $35.63^{*}$ & $57.67^{*}$ & $65.96^{*}$ & $8.83^{*}$ & $13.66^{*}$ & $19.45^{*}$ & $32.40^{*}$ & $50.79^{*}$ & $62.27^{*}$ \\
\hline & NP2K2 & $6.21^{*}$ & $9.79^{*}$ & $11.60^{*}$ & $33.07^{*}$ & $52.07^{*}$ & $64.22^{*}$ & $8.31^{*}$ & $12.13^{*}$ & $18.73^{*}$ & $31.64^{*}$ & $47.01^{*}$ & $60.03^{*}$ \\
\hline \multirow{8}{*}{ D2 } & NP1 & $7.78^{*}$ & $11.16^{*}$ & $13.38^{*}$ & $38.19^{*}$ & $61.54^{*}$ & $67.76^{\star}$ & $9.43^{*}$ & $16.66^{*}$ & $21.27^{*}$ & $33.39^{*}$ & $58.31^{*}$ & $65.10^{*}$ \\
\hline & NP2 & $6.32^{*}$ & $9.83^{\star}$ & $11.80^{*}$ & $35.46^{\star}$ & $55.46^{*}$ & $65.78^{*}$ & $9.24^{\star}$ & $14.62^{*}$ & $21.00^{*}$ & $32.96^{\star}$ & $55.02^{*}$ & $64.24^{*}$ \\
\hline & NK1 & $5.96^{*}$ & $9.78^{\star}$ & $11.60^{*}$ & $30.24^{*}$ & $51.30^{*}$ & $60.75^{*}$ & $7.96^{\star}$ & $11.83^{*}$ & $18.02^{*}$ & $31.28^{*}$ & $44.42^{*}$ & $59.53^{*}$ \\
\hline & NK2 & $5.90^{*}$ & $8.65^{*}$ & $11.42^{*}$ & $27.80^{*}$ & $45.84^{*}$ & $53.22^{*}$ & $8.88^{*}$ & $14.01^{*}$ & $20.44^{*}$ & $32.51^{*}$ & $52.25^{*}$ & $62.27^{*}$ \\
\hline & NP1K1 & $7.32^{\star}$ & $10.22^{*}$ & $12.07^{*}$ & $37.49^{*}$ & $58.48^{*}$ & $67.26^{*}$ & $9.33^{*}$ & $14.91^{*}$ & $21.20^{*}$ & $33.22^{*}$ & $56.80^{*}$ & $64.55^{\star}$ \\
\hline & NP1K2 & $5.91^{*}$ & $9.60^{*}$ & $11.56^{*}$ & $29.23^{*}$ & $50.74^{*}$ & $57.65^{\star}$ & $9.63^{*}$ & $18.46^{*}$ & $22.51^{*}$ & $33.95^{\star}$ & $64.24^{*}$ & $67.10^{*}$ \\
\hline & NP2K1 & $8.61^{*}$ & $14.20^{*}$ & $14.39^{*}$ & $39.43^{*}$ & $68.85^{*}$ & $70.19^{*}$ & $9.49^{\star}$ & $17.00^{*}$ & $21.80^{*}$ & $32.63^{*}$ & $62.68^{*}$ & $66.12^{*}$ \\
\hline & NP2K2 & $7.44^{\star}$ & $10.80^{*}$ & $12.46^{*}$ & $37.61^{*}$ & $61.11^{*}$ & $67.43^{*}$ & $8.20^{*}$ & $12.03^{*}$ & $18.08^{*}$ & $31.59^{*}$ & $46.24^{*}$ & $59.76^{*}$ \\
\hline \multicolumn{2}{|c|}{ LSD at $5 \%$} & 0.6 & 0.84 & 0.8 & 1.6 & 1.7 & 1.8 & 0.32 & 0.40 & 0.46 & 1.2 & 1.3 & 1.6 \\
\hline
\end{tabular}


Table 3 a: Effect of mixed fertilizer on pigments content ( $\mathrm{mg} / \mathrm{g} \mathrm{d}$ wt) in flag leaf of wheat plants grown in clay and loamy soil at tillering stage

\begin{tabular}{|c|c|c|c|c|c|c|c|c|c|c|c|c|c|}
\hline \multirow{2}{*}{\multicolumn{2}{|c|}{$\begin{array}{l}\text { Treatments } \\
\text { Parameters }\end{array}$}} & \multicolumn{6}{|c|}{ Clay } & \multicolumn{6}{|c|}{ Loamy } \\
\hline & & Chl a & Chl b & $a+b$ & a / b & Car. & T.pigments & Chl a & Chl b & $a+b$ & $\mathbf{A} / \mathbf{b}$ & Car. & T.pigments \\
\hline \multicolumn{2}{|c|}{ Cont -ve } & 1.19 & 0.86 & 2.05 & 1.38 & 0.55 & 2.6 & 1.16 & 0.86 & 2.02 & 1.34 & 0.54 & 2.56 \\
\hline \multicolumn{2}{|c|}{ Cont +ve } & 2.49 & 1.00 & 3.49 & 2.49 & 0.74 & 4.23 & 2.50 & 1.00 & 3.5 & 2.5 & 0.74 & 4.24 \\
\hline \multirow{8}{*}{ D1 } & NP1 & $4.69^{*}$ & $2.40^{*}$ & $7.09^{*}$ & $1.95^{\star}$ & $1.55^{\star}$ & $8.64^{\star}$ & $3.58^{*}$ & $1.39^{\star}$ & $4.97^{\star}$ & $2.57^{\star}$ & $1.13^{*}$ & $6.1^{*}$ \\
\hline & NP2 & $4.01^{*}$ & $1.98^{*}$ & $5.99^{*}$ & $2.02^{*}$ & $1.26^{*}$ & $7.25^{*}$ & $3.69^{*}$ & $1.48^{*}$ & $5.17^{\star}$ & $2.49^{*}$ & $1.21^{*}$ & $6.38^{*}$ \\
\hline & NK1 & $4.36^{*}$ & $2.22^{*}$ & $6.58^{\star}$ & $1.96^{*}$ & $1.38^{\star}$ & $7.96^{*}$ & $3.37^{*}$ & $1.20^{*}$ & $4.57^{*}$ & $2.80^{*}$ & $0.87^{*}$ & $5.44^{*}$ \\
\hline & NK2 & $4.52^{*}$ & $2.39^{*}$ & $6.91^{*}$ & $1.89^{*}$ & $1.53^{*}$ & $8.44^{*}$ & $3.23^{*}$ & $1.17^{\star}$ & $4.4^{*}$ & $2.76^{\star}$ & $0.85^{\star}$ & $5.25^{\star}$ \\
\hline & NP1K1 & $4.48^{\star}$ & $2.34^{*}$ & $6.82^{*}$ & $1.91^{*}$ & $1.40^{*}$ & $8.22^{*}$ & $3.59^{*}$ & $1.40^{*}$ & $4.99^{*}$ & $2.56^{*}$ & $1.14^{\star}$ & $6.13^{*}$ \\
\hline & NP1K2 & $3.85^{\star}$ & $1.86^{*}$ & $5.71^{*}$ & $2.06^{*}$ & $1.14^{\star}$ & $6.85^{\star}$ & $3.40^{*}$ & $1.23^{*}$ & $4.63^{*}$ & $2.76^{\star}$ & $0.90^{\star}$ & $5.53^{*}$ \\
\hline & NP2K1 & $3.76^{\star}$ & $1.81^{*}$ & $5.57^{\star}$ & $2.07^{\star}$ & $1.10^{*}$ & $6.67^{*}$ & $3.61^{*}$ & $1.42^{\star}$ & $5.03^{*}$ & $2.54^{*}$ & $1.14^{\star}$ & $6.17^{*}$ \\
\hline & NP2K2 & $3.60^{*}$ & $1.72^{*}$ & $5.32^{*}$ & $2.09^{*}$ & $0.99^{*}$ & $6.31^{*}$ & $3.57^{*}$ & $1.39^{*}$ & $4.96^{*}$ & $2.56^{*}$ & $1.11^{\star}$ & $6.07^{*}$ \\
\hline \multirow{8}{*}{ D2 } & NP1 & $4.17^{*}$ & $2.03^{*}$ & $6.2^{*}$ & $2.05^{\star}$ & $1.32^{\star}$ & $7.52^{*}$ & $4.17^{*}$ & $1.86^{*}$ & $6.03^{*}$ & $2.24^{\star}$ & $1.38^{*}$ & $7.41^{*}$ \\
\hline & NP2 & $3.74^{\star}$ & $1.76^{*}$ & $5.5^{\star}$ & $2.12^{*}$ & $1.05^{\star}$ & $6.55^{\star}$ & $3.73^{*}$ & $1.50^{*}$ & $5.23^{*}$ & $2.48^{*}$ & $1.21^{*}$ & $6.44^{*}$ \\
\hline & NK1 & $3.47^{\star}$ & $1.50^{*}$ & $4.97^{\star}$ & $2.31^{*}$ & $0.97^{*}$ & $5.94^{*}$ & $3.46^{*}$ & $1.25^{*}$ & $4.71^{*}$ & $2.76^{*}$ & $0.96^{*}$ & $5.67^{*}$ \\
\hline & NK2 & $3.19^{\star}$ & $1.44^{*}$ & $4.63^{*}$ & $2.21^{*}$ & $0.85^{\star}$ & $5.48^{\star}$ & $3.66^{*}$ & $1.44^{\star}$ & $5.1^{*}$ & $2.54^{\star}$ & $1.15^{\star}$ & $6.25^{\star}$ \\
\hline & NP1K1 & $3.94^{*}$ & $1.89^{*}$ & $5.83^{*}$ & $2.08^{\star}$ & $1.21^{*}$ & $7.04^{\star}$ & $3.76^{*}$ & $1.50^{*}$ & $5.26^{*}$ & $2.50^{\star}$ & $1.27^{\star}$ & $6.53^{*}$ \\
\hline & NP1K2 & $3.23^{*}$ & $1.50^{*}$ & $4.73^{*}$ & $2.15^{\star}$ & $0.96^{*}$ & $5.69^{*}$ & $4.73^{*}$ & $2.34^{*}$ & $7.07^{*}$ & $2.02^{*}$ & $1.60^{*}$ & $8.67^{*}$ \\
\hline & NP2K1 & $4.73^{\star}$ & $2.44^{*}$ & $7.17^{\star}$ & $1.93^{*}$ & $1.60^{\star}$ & $8.77^{*}$ & $4.36^{*}$ & $2.22^{*}$ & $6.58^{\star}$ & $1.96^{\star}$ & $1.40^{\star}$ & $7.98^{*}$ \\
\hline & NP2K2 & $3.98^{*}$ & $1.97^{*}$ & $5.95^{*}$ & $2.02^{*}$ & $1.24^{*}$ & $7.19^{*}$ & $3.49^{*}$ & $1.34^{*}$ & $4.83^{*}$ & $2.60^{*}$ & $0.99^{*}$ & $5.82^{*}$ \\
\hline \multicolumn{2}{|c|}{ LSD at $5 \%$} & 0.11 & 0.04 & 0.10 & 0.05 & 0.03 & 0.16 & 0.13 & 0.03 & 0.05 & 0.02 & 0.03 & 0.13 \\
\hline
\end{tabular}


Table $3 \mathrm{~b}$ : Effect of mixed fertilizer on pigments content ( $\mathrm{mg} / \mathrm{g} \mathrm{d} \mathrm{wt}$ ) in flag leaf of wheat plants grown in clay and loamy soil at heading stage

\begin{tabular}{|c|c|c|c|c|c|c|c|c|c|c|c|c|c|}
\hline \multirow{2}{*}{\multicolumn{2}{|c|}{$\begin{array}{l}\text { Treatments } \\
\text { Parameters }\end{array}$}} & \multicolumn{6}{|c|}{ Clay } & \multicolumn{6}{|c|}{ Loamy } \\
\hline & & Chl a & Chl b & $a+b$ & $\mathbf{a} / \mathbf{b}$ & Car. & $\begin{array}{l}\text { T.pigments } \\
\text {.pigments }\end{array}$ & Chl a & Chl b & $a+b$ & a / b & Car. & T. pigments \\
\hline \multicolumn{2}{|c|}{ Cont -ve } & 2.18 & 1.24 & 3.42 & 1.75 & 1.41 & 4.83 & 2.15 & 1.24 & 3.39 & 1.73 & 0.82 & 4.21 \\
\hline \multicolumn{2}{|c|}{ Cont +ve } & 3.48 & 1.38 & 4.86 & 2.52 & 1.47 & 6.33 & 3.49 & 1.38 & 4.87 & 2.52 & 1.02 & 5.89 \\
\hline \multirow{8}{*}{ D1 } & NP1 & $5.72^{\star}$ & $2.79^{*}$ & $8.51^{*}$ & $2.05^{\star}$ & $1.81^{*}$ & $10.32^{*}$ & $4.60^{*}$ & $1.78^{*}$ & $6.38^{*}$ & $2.58^{*}$ & $1.39^{\star}$ & $7.77^{\star}$ \\
\hline & NP2 & $4.97^{*}$ & $2.40^{*}$ & $7.37^{\star}$ & $2.07^{\star}$ & $1.54^{\star}$ & $8.91^{*}$ & $4.72^{*}$ & $1.88^{*}$ & $6.6^{*}$ & $2.51^{*}$ & $1.47^{\star}$ & $8.07^{\star}$ \\
\hline & NK1 & $5.16^{*}$ & $2.62^{*}$ & $7.78^{*}$ & $1.96^{*}$ & $1.64^{*}$ & $9.42^{*}$ & $4.22^{*}$ & $1.60^{*}$ & $5.82^{*}$ & $2.63^{*}$ & $1.17^{\star}$ & $6.99^{*}$ \\
\hline & NK2 & $5.51^{*}$ & $2.76^{*}$ & $8.27^{*}$ & $1.99^{*}$ & $1.79^{*}$ & $10.06^{*}$ & $3.35^{\star}$ & $1.57^{\star}$ & $4.92^{*}$ & $2.13^{*}$ & $1.15^{\star}$ & $6.07^{\star}$ \\
\hline & NP1K1 & $5.47^{*}$ & $2.74^{*}$ & $8.21^{*}$ & $1.99^{*}$ & $1.66^{*}$ & $9.87^{*}$ & $4.60^{\star}$ & $1.79^{*}$ & $6.39^{*}$ & $2.56^{*}$ & $1.40^{\star}$ & $7.79^{\star}$ \\
\hline & NP1K2 & $4.75^{\star}$ & $2.26^{*}$ & $7.01^{*}$ & $2.10^{*}$ & $1.40^{*}$ & $8.41^{*}$ & $4.51^{*}$ & $1.63^{*}$ & $6.14^{\star}$ & $2.76^{*}$ & $1.20^{*}$ & $7.34^{\star}$ \\
\hline & NP2K1 & $4.73^{*}$ & $2.21^{*}$ & $6.94^{*}$ & $2.14^{\star}$ & $1.40^{*}$ & $8.34^{*}$ & $4.63^{*}$ & $1.80^{*}$ & $6.43^{*}$ & $2.57^{\star}$ & $1.40^{*}$ & $7.83^{*}$ \\
\hline & NP2K2 & $4.46^{*}$ & $2.12^{*}$ & $6.58^{*}$ & $2.10^{*}$ & $1.29^{*}$ & $7.87^{\star}$ & $4.58^{\star}$ & $1.75^{\star}$ & $6.33^{*}$ & $2.61^{*}$ & $1.37^{\star}$ & $7.7^{*}$ \\
\hline \multirow{9}{*}{ D2 } & NP1 & $5.00^{*}$ & $2.43^{*}$ & $7.43^{*}$ & $2.05^{\star}$ & $1.62^{*}$ & $9.05^{*}$ & $4.87^{\star}$ & $2.26^{*}$ & $7.13^{*}$ & $2.15^{\star}$ & $1.64^{*}$ & $8.77^{\star}$ \\
\hline & NP2 & $4.56^{*}$ & $2.16^{*}$ & $6.72^{*}$ & $2.11^{*}$ & $1.35^{*}$ & $8.07^{*}$ & $4.75^{\star}$ & $1.90^{*}$ & $6.65^{\star}$ & $2.5^{*}$ & $1.51^{*}$ & $8.16^{*}$ \\
\hline & NK1 & $4.22^{*}$ & $1.90^{*}$ & $6.12^{*}$ & $2.22^{*}$ & $1.27^{*}$ & $7.39^{*}$ & $4.54^{\star}$ & $1.65^{\star}$ & $6.19^{*}$ & $2.75^{*}$ & $1.22^{*}$ & $7.41^{*}$ \\
\hline & NK2 & $3.35^{\star}$ & $1.87^{*}$ & $5.22^{*}$ & $1.79^{*}$ & $1.15^{*}$ & $6.37^{*}$ & $4.68^{*}$ & $1.84^{*}$ & $6.52^{*}$ & $2.54^{*}$ & $1.41^{*}$ & $7.93^{*}$ \\
\hline & NP1K1 & $4.84^{\star}$ & $2.27^{*}$ & $7.11^{*}$ & $2.13^{\star}$ & $1.47^{\star}$ & $8.58^{*}$ & $4.80^{\star}$ & $1.90^{\star}$ & $6.7^{\star}$ & $2.52^{\star}$ & $1.53^{\star}$ & $8.23^{\star}$ \\
\hline & NP1K2 & $4.18^{*}$ & $1.90^{*}$ & $6.08^{*}$ & $2.2^{*}$ & $1.22^{*}$ & $7.3^{*}$ & $5.72^{\star}$ & $2.74^{*}$ & $8.46^{*}$ & $2.08^{*}$ & $1.90^{*}$ & $10.36^{*}$ \\
\hline & NP2K1 & $5.72^{*}$ & $2.84^{*}$ & $8.56^{*}$ & $2.01^{*}$ & $1.90^{*}$ & $10.46^{*}$ & $5.16^{*}$ & $2.62^{*}$ & $7.78^{*}$ & $1.96^{*}$ & $1.66^{*}$ & $9.44^{*}$ \\
\hline & NP2K2 & $4.93^{\star}$ & $2.38^{*}$ & $7.31^{*}$ & $2.07^{*}$ & $1.52^{*}$ & $8.83^{*}$ & $4.56^{*}$ & $1.70^{*}$ & $6.26^{*}$ & $2.68^{*}$ & $1.25^{\star}$ & $7.51^{*}$ \\
\hline & LSD at $5 \%$ & 0.18 & 0.04 & 0.12 & 0.04 & 0.03 & 0.23 & 0.13 & 0.03 & 0.05 & 0.03 & 0.03 & 0.23 \\
\hline
\end{tabular}


Table $3 \mathrm{c}$ : Effect of mixed fertilizer on pigments content $(\mathrm{mg} / \mathrm{g} \mathrm{d} \mathrm{wt})$ in flag leaf of wheat plants grown in clay and loamy soil at anthesis stage

\begin{tabular}{|c|c|c|c|c|c|c|c|c|c|c|c|c|c|}
\hline \multirow{2}{*}{\multicolumn{2}{|c|}{$\begin{array}{l}\text { Treatments } \\
\text { Parameters }\end{array}$}} & \multicolumn{6}{|c|}{ Clay } & \multicolumn{6}{|c|}{ Loamy } \\
\hline & & Chl a & Chl b & $a+b$ & $\mathbf{a} / \mathbf{b}$ & Car. & T.pigments & Chl a & Chl b & $a+b$ & $\mathbf{a} / \mathbf{b}$ & Car. & T. pigments \\
\hline \multicolumn{2}{|c|}{ Cont -ve } & 3.62 & 1.30 & 4.92 & 2.78 & 0.88 & 5.8 & 2.31 & 1.30 & 3.61 & 1.77 & 0.87 & 4.48 \\
\hline \multicolumn{2}{|c|}{ Cont +ve } & 3.63 & 1.44 & 5.07 & 2.52 & 1.07 & 6.14 & 3.65 & 1.44 & 5.09 & $2 . .53$ & 1.07 & 6.16 \\
\hline \multirow{8}{*}{ D1 } & NP1 & $5.74^{\star}$ & $2.84^{*}$ & $8.58^{\star}$ & $2.02^{\star}$ & $1.88^{\star}$ & $10.46^{*}$ & $4.77^{*}$ & $1.83^{*}$ & $6.6^{\star}$ & $2.60^{*}$ & $1.44^{\star}$ & $8.04^{*}$ \\
\hline & NP2 & $5.15^{\star}$ & $2.44^{*}$ & $7.59^{\star}$ & $2.11^{\star}$ & $1.59^{\star}$ & $9.18^{*}$ & $4.88^{\star}$ & $1.92^{*}$ & $6.8^{\star}$ & $2.54^{\star}$ & $1.52^{\star}$ & $8.32^{*}$ \\
\hline & NK1 & $5.50^{*}$ & $2.66^{*}$ & $8.16^{\star}$ & $2.06^{\star}$ & $1.71^{*}$ & $9.87^{*}$ & $4.67^{*}$ & $1.64^{*}$ & $6.31^{*}$ & $2.84^{*}$ & $1.22^{*}$ & $7.53^{*}$ \\
\hline & NK2 & $5.66^{*}$ & $2.83^{*}$ & $8.49^{*}$ & $2.00^{*}$ & $1.86^{*}$ & $10.35^{\star}$ & $4.37^{*}$ & $1.61^{*}$ & $5.98^{*}$ & $2.71^{*}$ & $1.18^{*}$ & $7.16^{*}$ \\
\hline & NP1K1 & $5.62^{*}$ & $2.78^{*}$ & $8.4^{*}$ & $2.02^{*}$ & $1.73^{*}$ & $10.13^{*}$ & $4.79^{*}$ & $1.84^{*}$ & $6.63^{*}$ & $2.60^{*}$ & $1.45^{\star}$ & $8.08^{*}$ \\
\hline & NP1K2 & $4.90^{*}$ & $2.30^{*}$ & $7.2^{*}$ & $2.13^{*}$ & $1.47^{\star}$ & $8.67^{*}$ & $4.70^{*}$ & $1.68^{*}$ & $6.38^{*}$ & $2.79^{*}$ & $1.25^{\star}$ & $7.63^{*}$ \\
\hline & NP2K1 & $4.88^{*}$ & $2.25^{*}$ & $7.13^{*}$ & $2.16^{\star}$ & $1.42^{*}$ & $8.55^{\star}$ & $4.84^{*}$ & $1.86^{*}$ & $6.7^{*}$ & $2.60^{*}$ & $1.46^{*}$ & $8.16^{*}$ \\
\hline & NP2K2 & $4.74^{\star}$ & $2.16^{*}$ & $6.9^{*}$ & $2.19^{*}$ & $1.32^{*}$ & $8.22^{*}$ & $4.76^{\star}$ & $1.83^{*}$ & $6.59^{*}$ & $2.60^{*}$ & $1.42^{*}$ & $8.01^{*}$ \\
\hline \multirow{9}{*}{ D2 } & NP1 & $5.31^{*}$ & $2.47^{*}$ & $7.78^{\star}$ & $2.14^{\star}$ & $1.65^{\star}$ & $9.43^{*}$ & $5.03^{\star}$ & $2.30^{*}$ & $7.33^{\star}$ & $2.18^{*}$ & $1.71^{\star}$ & $9.04^{*}$ \\
\hline & NP2 & $4.82^{*}$ & $2.20^{*}$ & $7.02^{*}$ & $2.19^{*}$ & $1.38^{*}$ & $8.4^{\star}$ & $4.90^{*}$ & $1.94^{*}$ & $6.84^{*}$ & $2.48^{\star}$ & $1.56^{\star}$ & $8.4^{*}$ \\
\hline & NK1 & $4.61^{*}$ & $1.94^{*}$ & $6.55^{\star}$ & $2.37^{\star}$ & $1.29^{*}$ & $7.84^{\star}$ & $4.72^{*}$ & $1.69^{*}$ & $6.41^{*}$ & $2.79^{*}$ & $1.27^{\star}$ & $7.68^{*}$ \\
\hline & NK2 & $4.33^{*}$ & $1.91^{*}$ & $6.24^{\star}$ & $2.26^{*}$ & $1.18^{*}$ & $7.42^{\star}$ & $5.87^{*}$ & $1.88^{*}$ & $7.75^{\star}$ & $3.12^{*}$ & $1.47^{\star}$ & $9.22^{*}$ \\
\hline & NP1K1 & $5.08^{*}$ & $2.33^{*}$ & $7.41^{*}$ & $2.18^{*}$ & $1.54^{*}$ & $8.95^{\star}$ & $4.96^{*}$ & $1.94^{*}$ & $6.9^{*}$ & $2.55^{\star}$ & $1.58^{\star}$ & $8.48^{*}$ \\
\hline & NP1K2 & $4.37^{\star}$ & $1.94^{*}$ & $6.31^{*}$ & $2.25^{\star}$ & $1.29^{*}$ & $7.6^{*}$ & $5.50^{*}$ & $2.78^{*}$ & $8.28^{*}$ & $1.97^{\star}$ & $1.93^{*}$ & $10.21^{*}$ \\
\hline & NP2K1 & $5.87^{*}$ & $2.88^{*}$ & $8.75^{\star}$ & $2.03^{*}$ & $1.93^{*}$ & $10.68^{*}$ & $5.31^{*}$ & $2.66^{*}$ & $7.97^{*}$ & $1.99^{*}$ & $1.73^{*}$ & $9.7^{*}$ \\
\hline & NP2K2 & $5.12^{*}$ & $2.42^{*}$ & $7.54^{\star}$ & $2.11^{*}$ & $1.57^{*}$ & $9.11^{*}$ & $4.74^{*}$ & $1.78^{*}$ & $6.52^{*}$ & $2.66^{*}$ & $1.30^{*}$ & $7.82^{*}$ \\
\hline & LSD at $5 \%$ & 0.18 & 0.03 & 0.18 & 0.05 & 0.03 & 0.40 & 0.15 & 0.03 & 0.06 & 0.03 & 0.03 & 0.43 \\
\hline
\end{tabular}


Table 4: Effect of mixed fertilizers on yield and yield attributes of the yielded grains of wheat plant grown in clay and loamy soil

\begin{tabular}{|c|c|c|c|c|c|c|c|c|c|c|c|c|c|c|c|}
\hline \multirow{2}{*}{\multicolumn{2}{|c|}{$\begin{array}{c}\text { parameters } \\
\text { Treatments }\end{array}$}} & \multicolumn{2}{|c|}{ Grain yield / plant } & \multicolumn{2}{|c|}{ Straw yield / plant } & \multicolumn{2}{|c|}{ Crop yield / plant } & \multicolumn{2}{|c|}{ Harvest index } & \multicolumn{2}{|c|}{ Mobilization index } & \multicolumn{2}{|c|}{ Crop index } & \multicolumn{2}{|c|}{$\begin{array}{c}\text { Relative grain } \\
\text { yield }\end{array}$} \\
\hline & & Clay & Loamy & Clay & Loamy & Clay & Loamy & Clay & Loamy & Clay & Loamy & Clay & Loamy & Clay & Loamy \\
\hline \multicolumn{2}{|c|}{ Cont -ve } & 0.295 & 0.193 & 1.041 & 0.784 & 1.336 & 0.977 & 0.283 & 0.246 & 1.283 & 1.246 & 0.228 & 0.197 & 100.00 & 100.00 \\
\hline \multicolumn{2}{|c|}{ Cont +ve } & 0.352 & 0.256 & 1.243 & 0.981 & 1.596 & 1.237 & 0.281 & 0.260 & 1.281 & 1.260 & 0.220 & 0.206 & 119.32 & 132.64 \\
\hline \multirow{8}{*}{ D1 } & NP1 & $0.354^{*}$ & $0.339^{*}$ & $1.459^{*}$ & $0.677^{\star}$ & $1.813^{*}$ & $1.016^{*}$ & $0.242^{*}$ & ${ }^{*},, 0 \ldots$ & $1.242^{*}$ & $1.500^{*}$ & $0.195^{*}$ & $0.333^{*}$ & & $175.6^{*}$ \\
\hline & NP2 & $0.413^{*}$ & $0.283^{\star}$ & $1.925^{\star}$ & $0.710^{*}$ & $2.338^{*}$ & $0.993^{*}$ & $0.214^{*}$ & $\cdot, r 9 \Lambda *$ & $1.214^{\star}$ & $1.398^{*}$ & $0.176^{\star}$ & $0.284^{\star}$ & $140.0^{*}$ & $146.6^{\star}$ \\
\hline & NK1 & $0.397^{*}$ & $0.304^{*}$ & $1.126^{*}$ & $0.541^{*}$ & $1.523^{*}$ & $0.845^{\star}$ & $0.352^{*}$ & ${ }^{*}, 071$ & $1.352^{*}$ & $1.561^{*}$ & $0.260^{*}$ & $0.359^{*}$ & $134.5^{*}$ & $157.5^{\star}$ \\
\hline & NK2 & $0.216^{\star}$ & $0.428^{*}$ & $1.254^{*}$ & $1.413^{*}$ & $1.470^{*}$ & $1.841^{*}$ & $0.172^{*}$ & $0.309^{*}$ & $1.172^{*}$ & $1.309^{*}$ & $0.146^{*}$ & $0.288^{*}$ & $73.2^{*}$ & $221.7^{*}$ \\
\hline & NP1K1 & $0.214^{*}$ & $0.151^{*}$ & & & & $1.234^{*}$ & $0.279^{*}$ & 39 * & $79^{*}$ & & $0.218^{*}$ & & $72.5^{*}$ & $78.2^{*}$ \\
\hline & NP1K2 & $0.275^{\star}$ & $0.248^{*}$ & $1.527^{*}$ & $0.877^{\star}$ & $1.802^{*}$ & $1.125^{*}$ & $0.180^{*}$ & $0.282^{*}$ & $1.180^{*}$ & $1.282^{*}$ & $0.153^{*}$ & $0.222^{*}$ & $93.2^{*}$ & $128.4^{\star}$ \\
\hline & NP2K1 & & & & & $1.729^{*}$ & $1.645^{\star}$ & $0.247^{*}$ & $0.169^{*}$ & $1.247^{*}$ & & $0.198^{*}$ & $0.144^{\star}$ & & $123.3^{*}$ \\
\hline & NP2K2 & $0.457^{*}$ & $0.277^{\star}$ & $2.042^{*}$ & $1.288^{\star}$ & $2.499^{*}$ & $1.565^{\star}$ & $0.223^{*}$ & $0.215^{*}$ & $1.223^{\star}$ & $15^{\star}$ & $0.182^{*}$ & $0.176^{\star}$ & & $143.5^{\star}$ \\
\hline \multirow{9}{*}{ D2 } & NP1 & $0.629^{*}$ & $0.296^{\star}$ & $1.121^{*}$ & $0.819^{*}$ & $750^{*}$ & $1.115^{\star}$ & $0.561^{*}$ & 0.361 * & $1.561^{*}$ & $1.361^{*}$ & $0.359^{*}$ & $0.265^{\star}$ & $210.3^{*}$ & $153.3^{*}$ \\
\hline & NP2 & $0.388^{*}$ & $0.227^{*}$ & $0.907^{*}$ & $0.636^{*}$ & $1.295^{*}$ & $0.863^{*}$ & $0.427^{*}$ & $0.356^{*}$ & $1.427^{*}$ & $1.356^{*}$ & $0.299^{*}$ & $0.263^{*}$ & $131.5^{*}$ & $117.6^{*}$ \\
\hline & NK1 & $0.367^{\star}$ & $0.400^{*}$ & $1.197^{\star}$ & $0.817^{\star}$ & $1.564^{*}$ & $1.217^{*}$ & $0.304^{*}$ & 0.489 * & $1.304^{*}$ & $1.489^{*}$ & $0.234^{*}$ & & & 207.2* \\
\hline & NK2 & $0.202^{*}$ & $0.431^{*}$ & $0.907^{*}$ & $0.676^{*}$ & $1.109^{*}$ & $1.107^{*}$ & $0.224^{*}$ & $0.637^{*}$ & $1.224^{*}$ & $1.637^{*}$ & $0.184^{*}$ & $0.389^{*}$ & $68.4^{*}$ & $223.3^{*}$ \\
\hline & NP1K1 & $0.413^{*}$ & $0.392^{*}$ & $0.979^{*}$ & $0.952^{*}$ & $1.392^{*}$ & $1.344^{*}$ & $0.421^{*}$ & $0.411^{*}$ & $1.421^{*}$ & $1.411^{*}$ & $0.296^{*}$ & $0.291^{*}$ & $140.0^{*}$ & $203.1^{*}$ \\
\hline & NP1K2 & $0.610^{*}$ & $0.569^{*}$ & $1.680^{*}$ & $1.464^{\star}$ & $2.290^{*}$ & $2.033^{*}$ & $0.363^{*}$ & $0.388^{*}$ & $1.363^{*}$ & $1.388^{*}$ & $0.266^{\star}$ & $0.270^{*}$ & $206.7^{\star}$ & $294.8^{*}$ \\
\hline & NP2K1 & $0.687^{\star *}$ & $0.301^{*}$ & $2.140^{*}$ & & $2.827^{*}$ & $0.998^{*}$ & $0.321^{*}$ & $0.480^{*}$ & $1.321^{*}$ & $1.430^{*}$ & $0.243^{*}$ & $0.300^{*}$ & & $155.9^{*}$ \\
\hline & NP2K2 & $0.645^{\star}$ & $0.215^{\star}$ & $1.254^{\star}$ & 0.85 & $1.899^{\star}$ & $1.068^{*}$ & $0.514^{*}$ & $0.252^{*}$ & $1.514^{\star}$ & $1.252^{*}$ & $0.339^{*}$ & $0.201^{*}$ & $218.6^{*}$ & $111.3^{*}$ \\
\hline & LSD at $5 \%$ & 0.07 & 0.03 & 0.08 & 0.05 & 0.13 & 0.10 & 0.07 & 0.03 & 0.13 & 0.11 & 0.04 & 0.03 & 1.18 & 1.14 \\
\hline
\end{tabular}


Table 5: Effect of mixed fertilizers on protein content and total carbohydrates of the yielded grains of wheat plant grown in clay and loamy soil

\begin{tabular}{|c|c|c|c|c|c|}
\hline \multirow{2}{*}{\multicolumn{2}{|c|}{$\begin{array}{c}\text { parameters } \\
\text { Treatments }\end{array}$}} & \multicolumn{2}{|c|}{$\begin{array}{l}\text { Protein } \mathrm{mg} / \mathrm{g} \text { d.wt } \\
\mathrm{Gm} / 100 \mathrm{gm} \text { plant }\end{array}$} & \multicolumn{2}{|c|}{$\begin{array}{c}\text { Total carbohydrates } \mathrm{mg} / \mathrm{gd} . \mathrm{wt} \\
\text { gm/100 gm plant }\end{array}$} \\
\hline & & Clay & Loamy & Clay & Loamy \\
\hline \multirow{2}{*}{\multicolumn{2}{|c|}{$\begin{array}{l}\text { Cont -ve } \\
\text { Cont +ve }\end{array}$}} & 51.1 & 47.1 & 747.0 & 720.0 \\
\hline & & 74.1 & 70.2 & 754.5 & 741.6 \\
\hline \multirow{8}{*}{ D1 } & NP1 & $115.0^{*}$ & $69.0^{*}$ & $754.7^{*}$ & $753.2^{*}$ \\
\hline & NP2 & $91.4^{\star}$ & $68.0^{\star}$ & $759.7^{\star}$ & $746.1^{*}$ \\
\hline & NK1 & $69.0^{*}$ & $83.3^{*}$ & $758.5^{\star}$ & $749.1^{*}$ \\
\hline & NK2 & $76.4^{*}$ & $94.3^{*}$ & $733.1^{*}$ & $760.8^{*}$ \\
\hline & NP1K1 & $95.4^{*}$ & $88.5^{\star}$ & $732.6^{*}$ & $710.4^{*}$ \\
\hline & NP1K2 & $84.5^{\star}$ & $73.0^{*}$ & $744.9^{*}$ & $740.1^{*}$ \\
\hline & NP2K1 & $96.6^{*}$ & $75.3^{*}$ & $753.6^{*}$ & $738.1^{*}$ \\
\hline & NP2K2 & $116.4^{*}$ & $85.1^{*}$ & $762.6^{*}$ & $745.2^{*}$ \\
\hline \multirow{8}{*}{ D2 } & NP1 & $90.2^{*}$ & $95.4^{*}$ & $770.2^{*}$ & $748.0^{*}$ \\
\hline & NP2 & $105.2^{*}$ & $85.1^{*}$ & $757.8^{*}$ & $735.7^{*}$ \\
\hline & NK1 & $84.5^{*}$ & $94.3^{*}$ & $756.0^{*}$ & $758.7^{*}$ \\
\hline & NK2 & $88.5^{\star}$ & $97.1^{*}$ & $729.4^{*}$ & $761.0^{*}$ \\
\hline & NP1K1 & $69.2^{*}$ & $83.3^{\star}$ & $759.7^{\star}$ & $758.1^{\star}$ \\
\hline & NP1K2 & $75.3^{*}$ & $101.2^{*}$ & $769.6^{*}$ & $768.1^{*}$ \\
\hline & NP2K1 & $119.6^{*}$ & $73.0^{*}$ & $771.9^{*}$ & $748.7^{*}$ \\
\hline & NP2K2 & $77.0^{*}$ & $69.0^{*}$ & $770.7^{*}$ & $732.8^{*}$ \\
\hline \multicolumn{2}{|c|}{ LSD at $5 \%$} & 1.32 & 1.13 & 1.10 & 1.14 \\
\hline
\end{tabular}


J. Plant Production, Mansoura Univ., Vol. 3 (4): 639 - 653, 2012 
J. Plant Production, Mansoura Univ., Vol. 3 (4): 639 - 653, 2012 